\title{
ANALISIS MOTIVASI BELAJAR SISWA DAN KOMPETENSI GURU TERHADAP HASIL BELAJAR DAN IMPLIKASINYA TERHADAP REPUTASI SEKOLAH
}

\author{
Widayati $^{1}$, Kosasih $^{2}$, Theresia Widyanti ${ }^{3}$ \\ 1,2,3 Universitas Sangga Buana, YPKP, Bandung \\ ${ }^{1}$ korespondensi : widareysha79@gmail.com
}

\begin{abstract}
Student learning motivation and teacher competence are things that need to be considered in a learning process because they can directly or indirectly affect learning outcomes and can have an impact on school reputation. This research aims to determine student learning motivation, teacher competence, learning outcomes and school reputation, and to determine the effect of student learning motivation, teacher competence on learning outcomes and its implications on school reputation at SMK Negeri 5 Bandung both partially and simultaneously. The method used is descriptive verification. Data was collected by distributing questionnaires to teachers in SMK Negeri 5 Bandung. The data processing technique is done by path analysis, correlation, coefficient of determination test and hypothesis testing. The results showed that the responses regarding students' learning motivation were in the very good category, the teacher's competence was in the very good category, the learning outcomes obtained by students were in very good grades and the school's reputation was in the good category. Then student learning motivation and teacher competence have a positive and significant effect on learning outcomes and on school reputation simultaneously, and learning outcomes have a significant influence on school reputation at SMK Negeri 5 Bandung. Quality student learning outcomes or products supported by student learning motivation and qualified teacher competencies will also greatly affect the achievement or reputation of the school.
\end{abstract}

Keywords: Student learning motivation, teacher competence, learning outcomes, school reputation

\begin{abstract}
ABSTRAK
Motivasi belajar siswa dan kompetensi guru merupakan hal yang perlu diperhatikan dalam sebuah proses pembelajaran karena hal tersebut dapat secara langsung ataupun tidak langsung mempengaruhi hasil belajar dan dapat berdampak pada reputasi sekolah. Riset ini bertujuan ingin mengetahui motivasi belajar siswa, kompetensi guru, hasil belajar dan reputasi sekolah, dan untuk mengetahui pengaruh motivasi belajar siswa, kompetensi guru terhadap hasil belajar dan implikasinya pada reputasi sekolah di SMK Negeri 5 Bandung baik secara parsial dan secara bersama-sama. Metode yang digunakan adalah deskriptif verifikatif. Pengumpulan data dilakukan dengan menyebarkan kuesioner kepada para guru di lingkungan SMK Negeri 5 Bandung. Teknik pengolahan data dilakukan dengan analisis jalur, pengujian korelasi, pengujian koefisien determinasi dan pengujian hipotesis. Hasil penelitian menujukan bahwa tanggapan mengenai motivasi belajar siswa telah berada pada kategori sangat baik, kompetensi guru berada pada kategori sangat baik, hasil belajar yang diperoleh siswa berada pada nilai yang sangat baik dan reputasi sekolah pun berada pada kategori baik. Kemudian motivasi belajar siswa dan kompetensi guru berpengaruh positif dan signifikan terhadap hasil belajar dan terhadap reputasi sekolah secara simultan, dan hasil belajar memiliki pengaruh yang signifikan terhadap reputasi sekolah di SMK Negeri 5 Bandung. Hasil belajar atau produk siswanya berkualitas dengan didukung motivasi belajar siswa dan kompetensi guru yang berkualitas maka akan sangat berpengaruh besar pula terhadap prestasi atau reputasi sekolah.
\end{abstract}

Kata kunci: Motivasi belajar siswa, kompetensi guru, hasil belajar, reputasi sekolah

\section{PENDAHULUAN}

Mutu pendidikan dari setiap lembaga pendidikan akan meningkatkan reputasi sekolah di depan masyarakat baik sebagai masyarakat umum maupun para siswa dan alumni lembaga pendidikan tersebut. Reputasi lembaga pendidikan tentunya akan memiliki predikat yang ditentukan oleh publik secara objektif baik melalui survei maupun non survei, bahkan tanpa survei yaitu melalui 
getok tular dan komunikasi para alumni, peserta didik, bahkan orang tua menjadi evaluasi yang objektif tentang hal tersebut.

Sebagai asset penting yang dimiliki oleh organisasi atau lembaga adalah reputasi.

Kadang hal ini terlupakan padahal reputasi merupakan bukti atau eviden penting tentang keberadaan organisasi terkait ketercapaian dan kualitas yang dimilikinya. Keberadaan reputasi sekolah merupakan ketercapaian kualitas pendidikan yang sekaligus merupakan identitas dan bukti keberhasilan program yang telah dilaksanakan oleh sekolah dengan menunjukan terjadinya proses belajar mengajar yang produktif yang menghasilkan lulusan yang berkualitas yang dapat ditunjukan dengan diterimanya para lulusan baik di dunia pendidikan yang lebih tinggi ataupun pada dunia kerja serta dapat membentuk opini publik yang positif. Peran unit hubungan masyarakat didalam semua organisasi tak terkecuali di sekolah sangat diharapkan dapat menjadi garda terdepan perannya dalam menjaga, mempertahankan dan mengembangkan citranya reputasi.

SMKN 5 Bandung merupakan salah satu SMK Negeri yang ada di Kota Bandung, sebagai sekolah negeri harus memiliki reputasi yang baik. Salah satu hal yang dilihat oleh masyarakat sebagai pelanggan dan industri sebagai pengguna lulusan adalah hasil belajar yang diperoleh peserta didik, dan prestasi apa yang pernah diraih peserta didik serta sikap yang diperlihatkan peserta didik setelah lulus dari sekolah. Jika dilihat dari rata-rata nilai ujian masih kurang optimal dan dilihat dari hasil survey kepuasan pelanggan dalam hal ini pihak Dunia Usaha/Dunia Industri (DU/DI) masih ada nilai kepuasan yang dibawah 70. Kemudian dilihat dari penelusuran lulusan pun masih kurang terserap oleh dunia usaha atau dunia industri.

Hasil belajar yang dicapai oleh peserta didik masih belum maksimal sehingga selanjutnya penulis tertarik untuk menganalisis faktor apa yang mempengaruhi hasil belajar tersebut. Berdasarkan studi literasi yang dapat mempengaruhi keberhasilan dalam belajar salah satunya adalah sumber daya manusia (SDM) maka penulis tertarik untuk menganalisis dari segi motivasi belajar siswa dan kompetensi guru.

\section{TINJAUAN PUSTAKA}

\section{Teori Ilmu Manajemen}

Manajemen merupakan sebuah proses yang khas, yang terdiri dari tindakan-tindakan: perencanaan, pengorganisasian, penggiatan, dan tindakan pengawasan (controlling), yang dilakukan untuk menentukan serta mencapai sasaran-sasaran yang telah ditetapkan melalui pemanfaatan sumber daya manusia dan sumber-sumber lain [1].

Manajemen adalah kemampuan dan keterampilan untuk memperoleh hasil dalam rangka mencapai tujuan melalui kegiatan menggerakan orang lain [2].

Manajemen adalah ilmu dan seni untuk mengatur proses pemanfaatan sumber daya manusia dan sumber daya yang lain secara efektif dan efisien untuk mencapai tujuan tertentu [3]. 


\section{Teori Manajemen Pendidikan}

Manajemen pendidikan merupakan kegiatan yang memadukan sumber-sumber pendidikan supaya terpusat dalam usaha mencapai tujuan pendidikan yang telah ditetapkan [4].

Manajemen Pendidikan adalah ilmu dan seni mengelola sumber daya pendidikan untuk mencapai tujuan pendidikan secara efisien dan efektif [4].

Dengan demikian bahwa manajemen pendidikan merupakan ilmu dan seni untuk mengelola sumber daya dalam rangka mewujudkan suasana belajar dan proses belajar mengajar agar peserta didik dapat aktif mengembangkan dan mengoptimalkan potensi dirinya dengan kekuatan spiritual keagamaan yang dimiliki, pengendalian diri, kepribadian, kecerdasan, akhlak mulia, serta ketrampilan yang diperlukan dirinya, masyarakat, bangsa dan negara.

\section{Motivasi Belajar}

Terdapat 9 indikator [5]dalam motivasi dalam memotivasi belajar siswa yakni: 1) Selama melaksanakan tugas selalu tekun terus menerus sampai selesai; 2) Selalu ulet dalam menjalani setiap kesulitan tanpa putus asa; 3 ) Dalam berprestasi tidak selalu mengandalkan dukungan dari luar; 4) Selalu mempunyai keinginan untuk memperdalam segi ilmu pengetahuan yang didapatkan; 5) Mempunyai keinginan usaha untuk mendapatkan prestasi secara optimal; 6) Mempunyai keinginan atau minat terhadap penyelesaian permasalahan yang dihadapi orang dewasa.; 7) Selalu tetap pada pendirian dan keyakinan yang sudah dianggapnya sudah benar; 8) Mempunyai keinginan untuk mengejar apa yang menjadi ingin dituju pada jangka panjang walau harus menundanya saat ini; 9) Selalu gemar mencari solusi dalam menyelesaikan setiap permasalahan yang ada dalam soal.

\section{Kompetensi Guru}

Guru SMK/MAK harus memiliki kualifikasi akademik, kompetensi, dan sertifikat pendidik [6]. Kualifikasi akademik guru merupakan tingkat pendidikan minimal yang harus dipenuhi yang dibuktikan dengan ijazah. Kompetensi guru pada umumnya mencakup 4 (empat) kompetensi, yaitu kompetensi pedagogik, kepribadian, sosial, dan profesional yang dibuktikan dengan sertifikat pendidik.

\section{Hasil Belajar}

Hasil belajar itu merupakan proses yang menyebabkan adanya perubahan perilaku seseorang yang diukur terkait dengan pengetahuan (knowledge), sikap (attitude) dan keterampilan (skill) [7]. Diharapkan akan berdampak pada perubahan yakni ada peningkatan (progress) dan pengembangan (development) menuju kearah yang lebih baik dari sebelumnya.

Dengan demikian bahwa hasil belajar menunjukan tidak hanya berarti menghasilkan nilai yang baik semata akan tetapi dapat berupa perubahan sikap dan prilaku yang baik, tingkat penalaran yang meningkat, tingkat disiplin yang lebih baik, tingkat keterampilan yang meningkat serta perubahan-perubahan positif lainnya. 


\section{Reputasi Sekolah}

"Kesesuaian aplikasi visi dan misi perusahaan yang tertuang dalam identitas perusahaan yang mewujudkan dalam aktivitas keseharian perusahaan dan dipersepsi sama oleh sosial eksternal dan internal perusahaan" [8].

\section{METODE PENELITIAN}

Metode yang digunakan dalam penelitian ini adalah deskriptif verifikatif, dimana dalam pengambilan sampel menggunakan non probability sampling atau sampel jenuh yaitu semua populasi dijadikan sebagai sampel yang berjumlah 30 orang. Data karakteristik responden disajikan pada tabel 1 sebagai berikut :

Tabel 1 : Data Responden

\begin{tabular}{|c|c|c|c|}
\hline $\begin{array}{c}\text { Karakteristik } \\
\text { Responden }\end{array}$ & Kategori & Frekuensi & Persentase \\
\hline \multirow{2}{*}{$\begin{array}{l}\text { Status } \\
\text { Kepegawaian }\end{array}$} & PNS & 36 Guru & 43,37 \\
\hline & Non PNS & 47 Guru & 56,63 \\
\hline \multirow{2}{*}{ Pendidikan } & S1 & 72 Guru & 86,75 \\
\hline & $\mathrm{S} 2$ & 11 Guru & 13,25 \\
\hline \multirow{4}{*}{ Masa Kerja } & $\begin{array}{l}\text { Kurang } \\
\text { dari } 5 \\
\text { Tahun }\end{array}$ & 14 Guru & 16,87 \\
\hline & $\begin{array}{l}6-10 \\
\text { Tahun }\end{array}$ & 25 Guru & 30,12 \\
\hline & $\begin{array}{l}11-15 \\
\text { Tahun }\end{array}$ & 17 Guru & 20,48 \\
\hline & $\begin{array}{l}\text { Lebih } \\
\text { dari } 15 \\
\text { Tahun }\end{array}$ & 27 Guru & 32,53 \\
\hline
\end{tabular}

Alat analisis yang digunakan adalah path analysis atau analisis jalur dengan struktur model sebagai berikut :

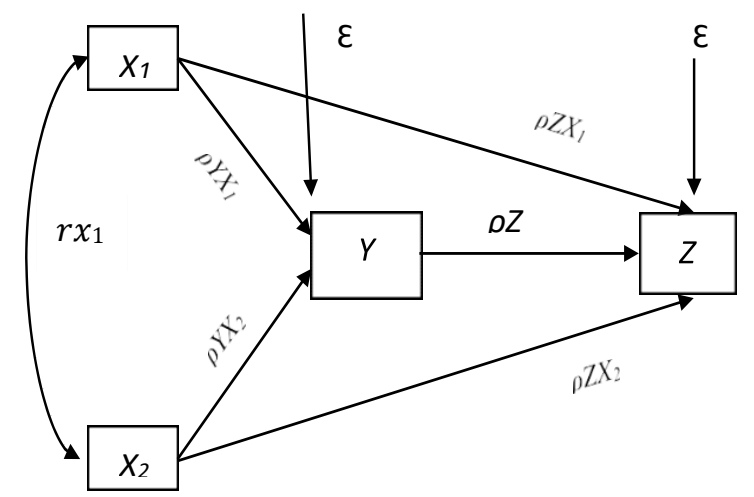

Gambar 1 : Diagram Jalur X1, X2 dan Y terhadap Z

Persamaan :

$\mathrm{Z}=\rho Z X 1 X 1+\rho Z X 2 X 2+\rho Z Y Y+\varepsilon 2$

Keterangan:

$X 1=$ Motivasi Belajar Siswa

$\mathrm{X} 2=$ Kompetensi Guru
$\mathrm{Y} \quad=$ Hasil Berlajar

$\mathrm{Z} \quad=$ Reputasi Sekolah

Analisis Jalur model tersebut terbagi menjadi 2 analisis jalur yaitu : 
1. Analisis jalur model $1: \mathrm{Y}=\rho y x 1 . X 1+$ $\rho y \times 2 . X 2+\varepsilon 1 \ldots$

2. Analisis jalur model $2: \mathrm{Z}=\rho z x 1 . X 1+$ $\rho z x 2 . X 2+p z y \cdot Y+\varepsilon 2$

\section{HASIL DAN PEMBAHASAN}

Uji Validitas, Uji Reliabilitas, dan Uji

\section{Normalitas}

Tingkat signifikansi pada penelitian ini yaitu $5 \%$. Hasil dari uji validitas pada penelitian ini dinyatakan valid dikarenakan semua $r$ hitung berada diatas $\mathrm{r}$ tabel, untuk uji reliabilitas dinyatakan reliabel dikarenakan semua nilai hitung cronbach alpha berada diatas nilai hitung. Pada uji normalitas dinyatakan berdistribusi secara normal karena berada diatas 0.05 .

\section{Persepsi Responden}

Motivasi belajar siswa secara rata rata berada pada kategori sangat tinggi dimana indicator terendah berada pada peserta didik masih kurang senang memecahkan soal-soal yang diberikan oleh guru sedangkan pada skor tertinggi ditunjukan pada indikator peserta didik terlihat lebih semangat ketika guru selalu memberikan pujian positif, hal tersebut menunjukan bahwa motivasi belajar siswa tinggi ketika mereka mendapatkan pujian positif. Kompetensi guru berada pada kategori sangat baik dimana indicator terendah berada pada kegiatan ekstrakurikuler untuk peserta didik guna mengembangkan bakat peserta didik, sedangkan indikator tertinggi berada pada guru bersikap terbuka terhadap peserta didik berkaitan dengan proses pembelajaran.
Hasil belajar berada pada kategori sangat baik dimana indikator terendah berada pada nilai peserta didik belum semuanya tuntas memenuhi Nilai KKM, sedangkan skor tertinggi ditunjukan pada indikator peserta didik menganggap penting dan bermanfaat terhadap pelajaran yang guru sampaikan. Reputasi sekolah berada pada kategori sangat baik dimana skor terendah berada pada indikator warga sekolah dan lingkungan sekitar mengenali Brand atau symbol dari sekolah dan Sekolah belum mempunyai prestasi di berbagai tingkat sampai internasional, sedangkan indikator tertinggi yaitu Sekolah memiliki tingkat kepercayaan yang tinggi dari masyarakat. Hal ini menunjukan bahwa reputasi sekolah sudah sangat baik karena masyarakat memiliki tingkat kepercayaan yang tinggi kepada sekolah.

\section{Analisis Jalur}

Analisis jalur digunakan untuk mengetahui dampak motivasi belajar siswa dan kompetensi guru terhadap hasil belajar dan implikasinya terhadap reputasi sekolah.

\section{Analisis Jalur Model 1}

Besarnya pengaruh variabel eksogen terhadap variabel intervening dapat diketahui dari nilai koefisien jalur dari tiap variabel eksogen terhadap variabel intervening. Tabel 2 dijelaskan nilai koefisien jalur motivasi belajar siswa dan kompetensi guru terhadap hasil belajar. 
Tabel 2: Koefisien Jalur X1, X2 terhadap Y

Coefficients $^{\mathrm{a}}$

\begin{tabular}{|ll|l|l|l|l|l|}
\hline \multirow{2}{*}{\multicolumn{2}{|c|}{}} & \multicolumn{2}{|l|}{$\begin{array}{l}\text { Unstandardized } \\
\text { Coefficients }\end{array}$} & $\begin{array}{l}\text { Standardized } \\
\text { Coefficients }\end{array}$ & $\mathrm{t}$ & Sig. \\
\cline { 2 - 7 } & $\mathrm{B}$ & Std. Error & Beta & & \\
\hline 1 & (Constant) & -.516 & 3.998 & & -.129 & .898 \\
\cline { 2 - 7 } & Motivasi Belajar (X1) & .248 & .102 & .256 & 2.416 & .018 \\
& Kompetensi Guru (X2) & .294 & .057 & .543 & 5.126 & .000 \\
\hline
\end{tabular}

a. Dependent Variable: Hasil Belajar (Y)

Sumber: Data Penelitian diolah 2021

Dari tabel diatas dapat dilihat besar pengaruh dari angka standardized coefficient, besar pengaruh motivasi belajar siswa (X1) terhadap hasil belajar (Y) 0.256 atau $25.6 \%$, untuk kompetensi guru (X2) terhadap Hasil belajar (Y) 0.543 atau $54.3 \%$.
Selanjutnya untuk mengetahui besar pengaruh variabel eksogen terhadap variable endogen pada analisis jalur model 1 maka dilakukan pengujian koefisien determinasi dengan hasil sebagai berikut :

Tabel 3: Koefisien Determinasi X1 dan X2 Terhadap Y

\begin{tabular}{|l|l|l|l|l|}
\hline Model & $\mathrm{R}$ & R Square & Adjusted R Square & $\begin{array}{l}\text { Std. Error of the } \\
\text { Estimate }\end{array}$ \\
\hline 1 & $.747^{\mathrm{a}}$ & .558 & .547 & 5.658762 \\
\hline
\end{tabular}

a. Predictors: (Constant), Kompetensi Guru (X2), Motivasi Belajar (X1)

Sumber: Data Penelitian diolah 2021

Berdasarkan tabel 2 dan 3 maka peneliti dapat membuat bagan analisis jalur model 1 sebagai berikut :

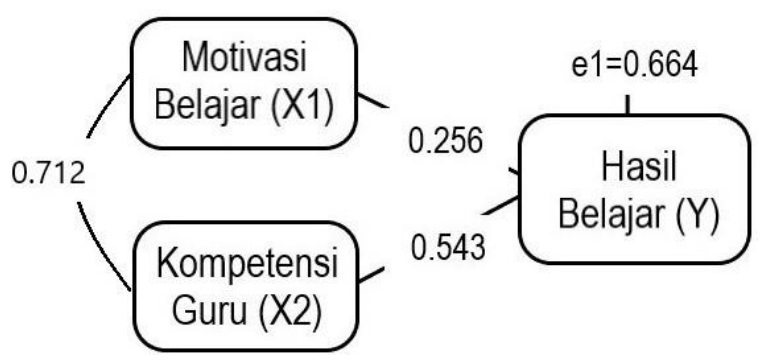

Gambar 2: Jalur Model 1

Berdasarkan gambar diatas maka persamaan struktur analisis jalur model 1 menurut Riduwan [9]

$\mathrm{Y}=\operatorname{pyx} 1 . \mathrm{X} 1+\operatorname{pyx} 2 . \mathrm{X} 2+\mathrm{e} 1$

$\mathrm{Y}=0,256 \mathrm{X} 1+0,543 \mathrm{X} 2+0,664$

\section{Uji Hipotesis Analisis Jalur Model 1}

Berdasarkan tabel 2 dapat dilihat bahwa nilai signifikansi masing masing variabel eksogen yaitu motivasi belajar siswa dan kompetensi guru adalah 0.018 dan 0.000 dimana nilai 
tersebut berada dibawah nilai signifikansi yang telah ditetapkan sebesar 0.05. Maka secara parsial motivasi belajar siswa dan kompetensi guru memiliki pengaruh yang signifikan terhadap hasil belajar.

Tabel 4: Tabel ANNOVA Analisis Jalur Model 1

\begin{tabular}{|c|c|c|c|c|c|c|}
\hline \multicolumn{7}{|c|}{ ANOVA $^{a}$} \\
\hline \multicolumn{2}{|c|}{ Model } & $\begin{array}{l}\text { Sum of } \\
\text { Squares }\end{array}$ & $\mathrm{df}$ & $\begin{array}{c}\text { Mean } \\
\text { Square }\end{array}$ & $\mathrm{F}$ & Sig. \\
\hline \multirow[t]{3}{*}{1} & Regression & 3233.865 & 2 & 1616.932 & 50.495 & $.000^{\mathrm{b}}$ \\
\hline & Residual & 2561.727 & 80 & 32.022 & & \\
\hline & Total & 5795.592 & 82 & & & \\
\hline
\end{tabular}

a. Dependent Variable: Hasil Belajar (Y)

b. Predictors: (Constant), Kompetensi Guru (X2), Motivasi Belajar (X1)

Pada tabel 4 terlihat bahwa nilai signifikansi menunjukan 0.00 dimana hasil tersebut berada dibawah maksimal standar eror yang telah ditetapkan yaitu sebesar $5 \%$ atau $0.00<0.05$ maka dapat dikatakan bahwa motivasi belajar siswa dan kompetensi guru secara simultan berpengaruh secara signifikan terhadap hasil belajar.

\begin{abstract}
Analisis Jalur Model 2
Pada analisis jalur model 2 mencakup pengaruh variabel motivasi belajar siswa dan kompetensi guru terhadap reputasi sekolah melalui hasil belajar. Dimana hasil nilai koefisien disajikan pada tabel berikut :
\end{abstract}

Tabel 5: Koefisien analisis jalur model 2

Coefficients $^{\mathbf{a}}$

\begin{tabular}{|ll|l|l|l|l|l|}
\hline \multirow{2}{*}{ Model } & \multicolumn{2}{|l|}{$\begin{array}{l}\text { Unstandardized } \\
\text { Coefficients }\end{array}$} & $\begin{array}{l}\text { Standardized } \\
\text { Coefficients }\end{array}$ & $\mathrm{t}$ & Sig. \\
\cline { 2 - 7 } & $\mathrm{B}$ & Std. Error & Beta & & \\
\hline 1 & (Constant) & 5.699 & 3.969 & & 1.436 & .155 \\
& Motivasi Belajar (X1) & .052 & .105 & .056 & .495 & .622 \\
& Kompetensi Guru (X2) & .202 & .066 & .386 & 3.081 & .003 \\
Hasil Belajar (Y) & .347 & .111 & .359 & 3.129 & .002 \\
\hline
\end{tabular}

a. Dependent Variable: Reputasi Sekolah (Z)

Sumber: Data Penelitian diolah 2021

Selanjutnya untuk mengetahui besar pengaruh variabel motivasi belajar siswa dan kompetensi guru terhadap reputasi sekolah, maka dilakukan uji koefisien determinasi dengan hasil sebagai berikut:

Tabel 6: Koefisien Determinasi analisis jalur model 2

Model Summary

\begin{tabular}{|l|c|r|r|r|}
\hline Model & $\mathrm{R}$ & R Square & $\begin{array}{c}\text { Adjusted R } \\
\text { Square }\end{array}$ & $\begin{array}{c}\text { Std. Error of } \\
\text { the Estimate }\end{array}$ \\
\hline 1 & $.734^{\mathrm{a}}$ & .539 & .522 & 5.617468 \\
\hline
\end{tabular}

a. Predictors: (Constant), Hasil Belajar (Y), Motivasi Belajar (X1), Kompetensi Guru (X2)

Sumber : Data yang diolah SPSS 
Berdasarkan tabel 5 dan 6 maka peneliti dapat membuat bagan analisis jalur model 2 sebagai berikut :

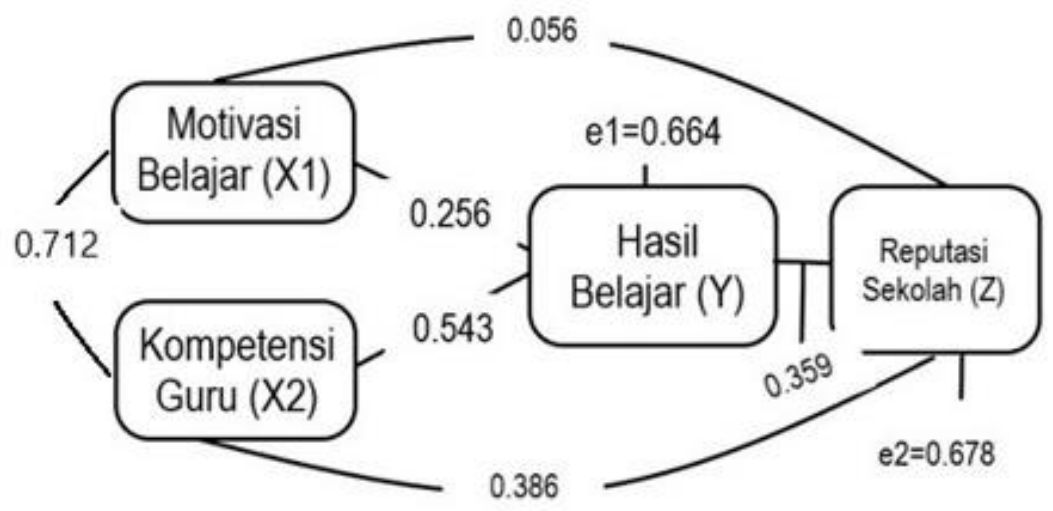

Gambar 3: Jalur model 2

Berdasarkan gambar diatas maka persamaan struktur analisis jalur model 2 menurut Riduwan [9]

$\mathrm{Z}=$ pzx $1 . X 1+$ pzx $2 \cdot X 2+$ pzy. $Y+e 2$ $Z=0,056 X 1+0,386 X 2+0,359 Y+0,678$

\section{Uji Hipotesis Analisis Jalur Model 2}

Dari tabel 5 terlihat bahwa nilai signifikansi pengaruh variabel motivasi belajar siswa terhadap reputasi sekolah sebesar 0.622 dimana hasil tersebut berada diatas nilai ketentuan standar sebesar 0,05 maka motivasi belajar siswa tidak berpengaruh langsung terhadap reputasi sekolah. Nilai signifikansi variabel kompetensi guru terhadap reputasi sekolah adalah sebesar 0.003 dimana hasil tersebut berada dibawah nilai ketentuan standar yang ditetapkan yaitu sebesar 0.05. Maka pengaruh kompetensi guru terhadap reputasi sekolah secara parsial dinyatakan signifikan.

\section{Tabel 7: Tabel ANNOVA analisis jalur model 2}

\begin{tabular}{ll|r|r|r|c|c|}
\hline Model & & Sum of Squares & \multicolumn{1}{c|}{ df } & Mean Square & F & Sig. \\
\hline 1 & Regression & 2918.537 & 3 & 972.846 & 30.829 & $.000^{b}$ \\
& Residual & 2492.920 & 79 & 31.556 & & \\
\multicolumn{1}{|l|}{ Total } & 5411.457 & 82 & & & \\
\hline
\end{tabular}
a. Dependent Variable: Reputasi Sekolah (Z)
b. Predictors: (Constant), Hasil Belajar (Y), Motivasi Belajar (X1), Kompetensi Guru (X2)

Pada tabel 7 terlihat bahwa nilai signifikansi menunjukan 0.00 dimana hasil tersebut berada dibawah maksimal standar eror yang telah ditetapkan yaitu sebesar 5\% atau $0.00<0.05$ maka dapat dikatakan bahwa motivasi belajar siswa, kompetensi guru dan hasil belajar secara simultan berpengaruh secara signifikan terhadap reputasi sekolah. Hal ini sejalan dengan penelitian yang telah dilakukan sebelumnya [10], [11], [12],[13][14].

\section{KESIMPULAN}

Berdasarkan hasil analisis data yang dilakukan pada riset/penelitian ini 
menunjukan bahwa motivasi belajar siswa dan kompetensi guru berpengaruh yang signifikan terhadap hasil belajar baik secara parsial maupun secara bersama-sama/simultan. Motivasi belajar siswa tidak berpengaruh langsung terhadap reputasi sekolah, namun secara tidak langsung dapat berpengaruh terhadap reputasi sekolah melalui hasil belajar. Kompetensi guru memberikan pengaruh yang signifikan terhadap hasil belajar siswa dan reputasi sekolah baik secara parsial maupun secara bersama-sama/ simultan.

\section{DAFTAR PUSTAKA}

[1] G. R. Terry and J. Smith D.F.M., Prinsip-prinsip manajemen / George R. Terry; penerjemah, J. Smith D.F.M. Jakarta: Bumi Aksara, 2012.

[2] S. P. Siagian, Manajemen Sumber Daya Manusia. Jakarta: Bumi Aksara, 2015.

[3] Malayu S.P. Hasibuan, Manajemen Sumber Daya Manusia. Jakarta: PT Bumi Aksara, 2016.

[4] Kompri, Manajemen pendidikan 1, Cet. 1. Bandung: Alfabeta, 2015.

[5] H. B. Uno, Teori Motivasi dan Pengukurannya: Analisis di Bidang Penidikan. Jakarta: Bumi Aksara, 2011.

[6] Undang-Undang Nomor 14 Tahun 2005, Undang-undang (UU) tentang Guru dan Dosen. Jakarta: SETNEG.
[7] Oemar Hamalik, Proses Belajar Mengajar. Jakarta: Bumi Aksara, 2011.

[8] Prayudi, Manajemen isu : pendekatan public relations. Yogyakarta: Pustaka Adipura, 2008.

[9] E. A. K. Riduwan, Cara Menggunakan dan Memaknai Analisis Jalur (Path Analysis). Bandung: Alfabeta, 2013.

[10] A. Kurniadi, I. Popoi, and M. Mahmud, "Pengaruh Kompetensi Profesional Guru Terhadap Motivasi Belajar Siswa," Jambura Econ. Educ. J., vol. 2, no. 1, pp. 1-11, 2020, doi: 10.37479/jeej.v2i1.4425.

[11] U. \& E. N. Siti Homisati Solihah, "Hubungan Antara Kompetensi Guru Dengan Motivasi Belajar Pada Siswa Boarding School SMP Plus ALAQSHA," J. Ilm. Psikol., vol. V, no. 1, pp. 490-499, 2012.

[12] D. D. \& I. W. Sri Hardianti Sartika, "Kompetensi Guru dan Motivasi Belajar Siswa Terhadap Hasil belajar Melalui Kebiasaan Belajar Siswa.," J. Manajerial, vol. 3, no. 4, 2018.

[13] S. dan M. Afif, "Pengaruh Komitmen dan Kompetensi Guru terhadap Perkembangan Jumlah Siswa pada Sekolah SMK Swasta di Bogor," J. Sos. Hum., vol. 5, no. 2, 2014.

[14] D. Rosdiana, "Pengaruh Kompetensi Guru dan Komitmen Mengajar terhadap Efektivitas Proses pembelajaran serta implikasinya pada hasil belajar siswa dalam mata pelajaran ekonomi," J. Penelit. Pendidik., vol. 16, no. 3, 2016. 